Науковий вісник Дьвівського національного університету ветеринарної медицини та біотехнологій імені С.3. Гжицького

\author{
Scientific Messenger of Lviv National University \\ of Veterinary Medicine and Biotechnologies
}

UDC 637.1

\title{
The development of technology of rickot cheese from whey, obtained using various coagulants
}

\author{
O.Y. Tsisaryk, L.Y. Musiy, I.M. Slyvka, V. Chrystyuk \\ Stepan Gzhytskyi National University of Veterinary Medicine and Biotechnologies Lviv, Ukraine
}

Article info

Received 11.09.2018

Received in revised form 09.10 .2018

Accepted 11.10.2018

Stepan Gzhytskyi National University of Veterinary Medicine and Biotechnologies Lviv, Pekarska Str., 50, Lviv, 79010, Ukraine.

Tel.: +38-098-132-31-63

E-mail:musiyluba@ukr.net
Tsisaryk, O.Y., Musiy, L.Y., Slyvka, I.M., \& Chrystyuk, V. (2018). The development of technology of rickot cheese from whey, obtained using various coagulants. Scientific Messenger of Lviv National University of Veterinary Medicine and Biotechnologies. 20(90), 40-45. doi: $10.32718 /$ nvlvet 9009

The problem of obtaining and rational use of whey proteins in human nutrition today is solved all over the world, traditional methods are being improved and new, more effective ways of processing milk whey, aimed at maximizing the withdrawal and use of its proteins, are being developed. The aim of the research was to develop the technology of albumin cheese ricotta from serum derived by the action of various coagulants. The raw material for cheese production was serum. For the study, two samples of cheese (with a threefold repetition) were made: Sample 1 - using serum formed during the fermentation of proteins with the participation of citric acid (normalized mixture + enzyme + citric acid); Sample 2 - using serum formed during protein mixing with the direct introduction of the fermentation culture (normalized mixture + enzyme + culture + calcium chloride). Determination of organoleptic and physico-chemical parameters in samples of albumin cheese, obtained from the developed technology, was carried out immediately after manufacture. The study of organoleptic characteristics of cheeses showed a similarity of indicators in samples 1 and 2. In particular, it was stated that pure, fresh taste and smell, with a specific albumin flavor, without foreign flavors and odors. Consistency in 1 sample was homogeneous, creamy, in 2 samples it was tender, but with a slight splinting. The color of the cheeses was white uniform throughout the mass. The lower acidity in the sample 2, which was at $17^{\circ} \mathrm{T}$, whereas in the sample 2 was higher $-20^{\circ} \mathrm{T}$. This, in particular, is explained by the use of citric acid for coagulation. The changes of microbiological parameters in the raw materials during storage, which consisted in the growth of the number of mesophilic anaerobic and optional aerobic microorganisms in two samples of cheese, were established. Given the permissible level of the number of mesophilic anaerobic and optional aerobic microorganisms in cheese not more than $1 \times 10^{5} \mathrm{CFU} / \mathrm{g}$, the shelf life of two samples of cheese for 5 days. Indicators of titrated acidity during storage were correlated with changes in the number of mesophilic anaerobic and optional aerobic microorganisms. The mass fraction of moisture in the samples of cheese in the process of their storage decreased.

Key words: serum proteins, ricotta cheese, technology, serum whey, organoleptic carriers, physicochemical parameters, microbiological indices.

\section{Розроблення технології сиру рікотта з сироватки, отриманої із застосуванням різних коагулянтів}

\author{
О.Й. Цісарик, Л.Я. Мусій, І.М. Сливка, В. Христюк
}

Львівський національний університет ветеринарної медицини та біотехнологій імені С.3. Гжицького, м. Львів, Украӥна

Проблема отримання та раціонального використання сироваткових білків у харчуванні людини сьогодні вирішується у всьому світі, удосконалюються традииійі і створюються нові, ефективніші способи перероблення молочної сироватки, спрямовані на максимальне вилучення і використання ї̈ білків. Метою досліджень було розробити технологію альбумінного сиру рікотта із сироватки, одержаної за дї різних коагулянтів. Сировиною для виготовлення сиру була підсирна сироватка. Для дослідження було виготовлено два зразки сиру (з триразовим повторенням): зразок 1 - із використанням сироватки, шзо утворилася при зсіданні білків за участю лимонної кислоти (нормалізована суміш + сичужний фермент + лимонна кислота); зразок 2 - із використанням сироватки, ияо утво- 
рилася при зсіданні білків за участю заквашувальної культури прямого внесення (нормалізована суміш + сичужний фермент + заквашувальна культура + хлористий кальцій). Визначення органолептичних та фізико-хімічних показників у зразках альбумінового сиру рікотта, отриманих за розробленою технологією, проводили відразу після виготовлення. Дослідження органолептичних показників сирів показало подібність показників у зразках 1 i 2. Зокрема, констатовано чистий, свіжий смак $i$ запах, зі специфічним альбуміновим присмаком, без сторонніх присмаків $i$ запахів. Консистениія у 1 зразку була однорідною, кремоподібною, тоді я у 2 зразку вона була ніжною, проте з незначною крупчастістю. Колір сирів був білий рівномірний по всій масі. При дослідженні титрованоӥ кислотності виявлено нижчу кислотність у зразку 2, щзо була на рівні $17{ }^{\circ} \mathrm{T}$, тоді як у зразку 2 цей показник був вищим - $20^{\circ} \mathrm{T}$. Це, зокрема, пояснюється застосуванням лимонної кислоти для зсідання білків. Встановлено зміни мікробіологічних показників в сирі протягом зберігання, які полягали у зростанні КМАФАнМ у двох зразках сиру. 3 огляду допустимого рівня КМАФАнМ у сирі не більше $1 \times 10^{5}$ КУО/г, термін зберігання двох зразків сиру 5 діб. Показники титрованої кислотності протягом зберігання корелювали із зміною КМАФАнМ. Масова частка вологи у зразках сиру у процесі їх зберігання знижувалася.

Ключові слова: сироваткові білки, сир рікотта, технологія, підсирна сироватка, органолептичні показники, фізико-хімічні показники, мікробіологічні показники.

\section{Вступ}

У сучасних умовах розвитку ринку харчових продуктів вцілому і молочних, зокрема, основними тенденціями підвищення ефективності виробництва й забезпечення конкурентоспроможності вітчизняної продукції є раціональне використання всіх складових молока під час його переробки та поліпшення споживчих властивостей продукту (Hramcov and Vasilisin, 2003; Cisaryk et al., 2014; Bilyk et al., 2017).

Актуальним завданням сьогодення є зростання випуску білкових молочних продуктів (сирів), технології яких засновані на коагуляції казеїну, що обумовлює збільшення кількості молочної сироватки, яка є побічним продуктом цих виробництв і джерелом біологічно цінних сироваткових білків (Mironenko and Chorej, 2009; Silva et al., 2012). 3 огляду на високу біологічну цінність сироваткових білків, їх можна розглядати як найперспективнішу сировину при виробництві м'яких сирів. Це дозволить значно поповнити існуючий асортиментний ряд високоякісними i недорогими продуктами, підвищити рентабельність виробництва, зменшити забруднення довкілля, збільшити ресурси повноцінних продуктів харчування. До таких продуктів відноситься альбумінний сир рікотта (Grek et al., 2010).

Сучасний ринок харчових продуктів в нашій країні потребує виготовлення нових продуктів, необхідність розробки технологій яких обумовлена, в першу чергу, незбалансованістю раціонів харчування, дефіцитом необхідних для організму мікронутрієнтів, погіршенням екологічної ситуації, а також низькою якістю продуктів харчування, виготовлених з використанням численних хімічних консервантів і ароматизаторів (Hramcov et al., 2009). Згідно рекомендацій ВОO3 i ФАО доза оптимальної потреби в білку становить $60 \ldots 100$ грам на добу або $12 \ldots 15 \%$ від загальної калорійності їжі. В загальній кількості енергії на частку білка тваринного і рослинного походження припадає по $6 \ldots 8 \%$. У перерахунку на 1 кг маси тіла потреба білка у дорослої людини в середньому дорівнює близько 1 грам, тоді як для дітей, залежно від віку, вона коливається від 1,05 до 4,0 г (Fox and Mulvihill, 1982; Farrell et al., 2004). Молочна сироватка $є$ джерелом повноцінних білків, тому в останній час спостерігається значне зацікавлення молочною сироваткою i продуктами її перероблення, з огляду використання їх як функціональних інгредієнтів для харчової та фар- мацевтичної промисловості (Shergin and Kurtova, 2006; Silva et al., 2012).

Сироваткові білки за вмістом життєво необхідних незамінних амінокислот (лізину, триптофану, метіоніну, треоніну, цистеїну) є найбільш біологічно цінними білками молока, вони швидко перетравлюються організмом людини без утворення побічних продуктів i забезпечують кращі регенеративні можливості для відновлення білків печінки, гемоглобіну та плазми крові (Fox and Mulvihill, 1982). Тому їх рекомендовано використовувати для створення продуктів лікувального і профілактичного призначення.

Вітчизняний асортимент м'яких сирів, альбумінових і сирних паст, у виробництві яких можна використовувати білки молочної сироватки, невеликий (Lucey et al., 2003; Hramcov and Vasilisin, 2004). 3a даними А.Г. Храмцова (2008), П.Г. Нестеренка (2008), Н.А. Епштейна (1989), В.А. Онопрійко (2002), A. Corsetti (2001), I. Drgalic (2004), A. Irigoyen (2002) та ін. 3 сироваткових білків виготовляють альбумінове молоко, альбуміновий кисломолочний сир, альбуміновий мус, сирну масу “Кавказ" тощо. У багатьох країнах застосування сироваткових білків покладене в основу технології термокислотних сирів типу "Рікотта”, сировиною для виробництва яких є підсирна сироватка 3 додаванням або без додавання коров'ячого чи овечого молока (Hramcov and Vasilisin, 2004). Сир "Рікотта" - традиційний італійський сир, який отримують при обробленні підсирної сироватки шляхом виділення білка за дії високих температур та лимонної або оцтової кислот. Назва сиру у перекладі із італійської мови означає повторно зварений (cotta - “варіння”, ri - префікс, який означає повторення). Сир рікотта складається головним чином із $\alpha$ лактальбуміну, $\beta$-лактоглобуліну, мінеральних солей, лактози і води та відноситься до свіжих сирів за рахунок м'якого солодкуватого смаку, кремоподібної, але в той же час злегка зернистої консистенції (Manderson et al., 1998). В Росії аналогічний продукт був представлений сирною масою “Кавказ”, проте короткі терміни зберігання сирної маси (72 години) і низькі органолептичні показники не дозволили широко організувати ï виробництво. На базі цієї технології у Всеросійському науково-дослідному інституті комплексного використання молочної сировини (м. Ставрополь) створена сучасна вдосконалена технологія продукту м'який термокислотний сир “Кавказ”, сировиною для виробництва якого є суміш 10\% молока і $90 \%$ підсир- 
ної сироватки. Термін зберігання цього продукту становить не більше 7 діб (Grek et al., 2010).

Альбуміновий сир за класичною технологією отримують відварюванням із молочної сироватки. Сироватку, отриману під час виробництва сиру, фільтрують, нагрівають до $93 \ldots 95{ }^{\circ} \mathrm{C}$ і витримують у ємностях при цій температурі 2...3 год. Далі іï охолоджують холодною водою, що міститься у міжстінному просторі. Сироватку зливають через штуцер. Альбуміновий згусток, що залишився, вибирають у лавсанові мішки і пресують до отримання продукту із вмістом вологи не більше $80 \%$. Готовий сир має кремовий колір і чистий смак 3 характерним присмаком альбуміну (Hramcov and Vasilisin, 2004).

Проблема отримання та раціонального використання сироваткових білків у харчуванні людини сьогодні вирішується у всьому світі, удосконалюються традиційні і створюються нові, ефективніші способи перероблення молочної сироватки, спрямовані на максимальне вилучення і використання ії білків. Однак, молокопереробні заводи України практично не випускають альбумінові сири. В той же час, зарубіжний досвід їх виробництва і використання в харчовій промисловості свідчить про необхідність технологічних розробок у цьому напрямі.

Метою досліджень було розробити технологію альбумінного сиру рікотта із сироватки, одержаної за дії різних коагулянтів.

\section{Матеріал і методи досліджень}

Експериментальні дослідження розроблення технології альбумінного сиру рікотта проводились у лабораторії кафедри технології молока і молочних продуктів Львівського національного університету ветеринарної медицини та біотехнологій імені С.3. Гжицького. Сировиною для виготовлення сиру була підсирна сироватка, отримана при виробництві сиру моцарелла. Для дослідження було виготовлено два зразки сиру (з триразовим повторенням):

- зразок 1 - із використанням сироватки, що утворилася при зсіданні білків за участю лимонної кислоти (нормалізована суміш + сичужний фермент + лимонна кислота);

- зразок 2 - із використанням сироватки, що утворилася при зсіданні білків за участю заквашувальної культури прямого внесення (нормалізована суміш + сичужний фермент + заквашувальну культура + хлористий кальцій).

Пакували сир у полімерні плівки по 200 г. Зберігали 5 діб при температурі $8^{\circ} \mathrm{C}$.

У сировині досліджували органолептичні та фізикохімічні показники (масову частку жиру, вміст сухих речовин, лактози, густину, титровану та активну кислотність). У зразках сиру визначали органолептичні, фізико-хімічні (масову частку сухих речовин, білка, вологи, титровану кислотність) та мікробіологічні показники. Використали загальноприйняті методи.

\section{Результати та їх обговорення}

Для виробництва м'якого сиру рікотта використовували підсирну сироватку, що утворилась при виробництві сиру моцарелла. У наших дослідженнях було використано сироватку 3 коров'ячого молока, що утворилася при виробництві сиру моцарелла за використання для зсідання білків лимонної кислоти (зразок 1) та заквашувальної культури прямого внесення (зразок 2). У результаті проведеної органолептичної оцінки (табл. 1) встановлено, що підсирна сироватка характеризувалась чистим, злегка кислуватим, властивим молочній сироватці, смаком і запахом; солом'яно-жовтим кольором, однорідною консистенцією із наявністю незначного білкового осаду.

\section{Таблиця 1}

Органолептичні показники підсирної сироватки

\begin{tabular}{|c|c|c|}
\hline \multirow{2}{*}{$\begin{array}{c}\text { Назва } \\
\text { показника }\end{array}$} & \multicolumn{2}{|c|}{ Характеристика } \\
\hline & Зразок 1 & Зразок 2 \\
\hline $\begin{array}{l}\text { Зовнішній } \\
\text { вигляд, колір }\end{array}$ & $\begin{array}{l}\text { Однорідна рідина солом'яно-жовтого кольору, } \\
\text { без сторонніх домішок, } 3 \text { незначним білковим } \\
\text { осадом }\end{array}$ & $\begin{array}{l}\text { Однорідна рідина лимонно-жовтого кольору, рів- } \\
\text { номірний по всій масі, без сторонніх домішок, } 3 \\
\text { незначним білковим осадом }\end{array}$ \\
\hline Смак і запах & $\begin{array}{l}\text { Чистий, властивий молочній сироватці, злегка } \\
\text { кислуватий, без сторонніх присмаків і запахів }\end{array}$ & $\begin{array}{l}\text { Чистий, властивий молочній сироватці, злегка } \\
\text { кислуватий, без сторонніх присмаків і запахів }\end{array}$ \\
\hline
\end{tabular}

Суттєвих відмінностей за органолептичними властивостями не встановлено, проте в результаті проведення аналізу фізико-хімічних показників складу сироваток були виявлені деякі відмінності (табл. 2). Основними досліджуваними фізико-хімічними показниками сироватки є титрована та активна кислотність. На кислотність сироватки, крім кислотності самого молока, також суттєво впливає спосіб отримання основного продукту. Оскільки в обох випадках основний продукт - сир моцарелла, то в нашому дослідженні основний вплив на кислотність сироватки мав спосіб зсідання білків. При дослідженні титрованої кислотності виявлено нижчу кислотність у зразку 2, що була на рівні $17^{\circ} \mathrm{T}$, тоді як у зразку 2 цей показник був вищим $-20^{\circ} \mathrm{T}$.

\section{Таблиця 2}

Фізико-хімічні показники підсирних сироваток

\begin{tabular}{lcc}
\hline \multicolumn{1}{c}{ Показники } & \multicolumn{2}{c}{ Зразки сироватки } \\
\cline { 2 - 3 } & Зразок 1 & Зразок 2 \\
\hline Масова частка жиру, \% & 0,3 & 0,28 \\
Вміст лактози, \% & 4,25 & 4,32 \\
Вміст сухих речовин, \% & 5,67 & 5,65 \\
Густина, кг/ ${ }^{3}$ & 1021 & 1019 \\
Титрована кислотність, ${ }^{\circ} \mathrm{T}$ & 20 & 17 \\
Активна кислотність, од. $\mathrm{pH}$ & 6,46 & 6,68 \\
\hline
\end{tabular}


Це пояснюється застосуванням лимонної кислоти для зсідання білків при виробництві сиру моцарелла у зразку 1. Технологічна схема виробництва м'якого сиру рікотта при використанні сироватки, що утворилися при виробництві сиру моцарелла за використання для зсідання білків лимонної кислоти та заквашувальної культури прямого внесення, представлена на рисунку 1.

Оцінка якості сировини (підсирної сироватки)

$$
\begin{gathered}
\text { Фільтрування сироватки } \\
\text { Відварювання альбумінів } \mathrm{t}=85 \ldots 95{ }^{\circ} \mathrm{C} \\
\text { з витримуванням } 2-3 \text { год. } \\
\text { Відділення білкової маси }
\end{gathered}
$$

Самопресування та пресування сирної маси:

$$
\begin{gathered}
\mathrm{t}=(19 \pm 1){ }^{\circ} \mathrm{C}, \tau=1,5 \ldots 2,0 \text { год. } \\
\text { Фасування, пакування } \\
\text { Зберігання: } \mathrm{t}=(4 \pm 2){ }^{\circ} \mathrm{C}, \tau \leq 5 \text { діб }
\end{gathered}
$$

Рис. 1. Технологічна схема виробництва альбумінового сиру рікотта

Після оцінки якості підсирної сироватки, та фільтрування, іiі підігрівали до температури $85 \ldots 90{ }^{\circ} \mathrm{C}$ i витримували 2 год. При вивченні процесу теплової коагуляції білків сироватки встановлено, що максимальне виділення білків спостерігається в ізоелектричній точці альбумінової фракції сироваткових білків при кислотності $37^{\circ} \mathrm{T}$ i pH 4,55. Оптимальна температура при цьому становить $95^{\circ} \mathrm{C}$, а тривалість витримування - не менше 25 хв. Тому, нами було обрано виділення сироваткових білків методом теплової коагуляції. Після денатурації сироваткових білків відділення білкової маси здійснювали фільтрацією через полотно. В подальшому сирну масу залишали для самопресування. При самопресуванні необхідно підтримувати температуру $18 \ldots 20{ }^{\circ} \mathrm{C}$. Самопресування застосовують для відділення залишків сироватки від згустку та одержання сиру зі стандартним вмістом вологи. Самопресування здійснювали протягом $1,5 \ldots .2,0$ год.

Визначення органолептичних та фізико-хімічних показників якості у зразках альбумінового сиру рікотта, отриманих за розробленою технологією, проводили відразу після виготовлення. Дослідження органолептичних показників сирів показало (табл. 3) подібність показників у зразках 1 і 2. Зокрема, констатовано чистий, свіжий смак і запах, зі специфічним альбуміновим присмаком, без сторонніх присмаків і запахів. Консистенція у 1 зразку була однорідною, кремоподібною, тоді як у 2 зразку вона була ніжною, проте $з$ незначною крупчастістю. Колір сиру у двох зразках був білим рівномірним по всій масі.

Таблиця 3

Органолептичні показники сиру рікотта

\begin{tabular}{lll}
\hline \multirow{2}{*}{ Назва } & \multicolumn{2}{c}{ Характеристика } \\
\cline { 2 - 3 } показника & \multicolumn{2}{c}{ Зразок 2 } \\
\hline Смак і запах & Чистий, свіжий, зі специфічним альбуміновим & Чистий, свіжий, зі специфічним альбуміновим \\
& присмаком, без сторонніх присмаків і запахів & присмаком, без сторонніх присмаків і запахів \\
Консистенція & Однорідна, кремоподібна & Однорідна, ніжна, з незначною крупчастістю \\
Колір & Білий рівномірний по всій масі & Білий рівномірний по всій масі \\
\hline
\end{tabular}

За фізико-хімічними показникам, що характеризують якість продукту, нами виявлено незначні різниці між зразками 1 і 2 (табл. 4).

\section{Таблиця 4}

Фізико-хімічні показники та вихід альбумінного сиру рікотта

\begin{tabular}{lcc}
\hline \multirow{2}{*}{\multicolumn{1}{c}{ Показники }} & \multicolumn{2}{c}{ Альбумінний сир рікотта } \\
\cline { 2 - 3 } & Зразок 1 & Зразок 2 \\
\hline Вихід сиру, \% & 4,2 & 3,7 \\
Масова частка сухих & 20,5 & 19,9 \\
речовин, \% & & \\
Масова частка білка, \% & 18,3 & 18,1 \\
Титрована кислотність, ${ }^{\circ} \mathrm{T}$ & 85 & 79 \\
Масова частка вологи, \% & 78 & 75 \\
\hline
\end{tabular}

Встановлено, що вихід сиру у зразку 1 на 12\% вищий порівняно із зразком 2. Вища титрована кислотність сироватки, що утворилися при виробництві сиру моцарелла за використання для зсідання білків лимонної кислоти призвела до вищої титрованої кислотності сиру рікотта на $6^{\circ} \mathrm{T}$ порівняно із зразком 2. При визначенні масової частки вологи, встановлено, що вона була в межах $65 \ldots 68 \%$.

Для встановлення терміну зберігання альбумінового сиру рікотта були проведені дослідження органолептичних, фізико-хімічних та мікробіологічних показників в процесі зберігання при температурі $(4 \pm 2){ }^{\circ} \mathrm{C}$ впродовж 6 діб.Упродовж перших трьох діб зберігання органолептичні показники обох зразків практично не змінювалися. При подальшому зберіганні, на 5 добу, у двох зразках сиру спостерігався виражений гіркуватий смак і запах.

При визначенні зміни титрованої кислотності в процесі зберігання впродовж 6 діб (рис. 2) встановлено, що з часом титрована кислотність зростає у двох зразках. За 6 діб зберігання у зразку 1 титрована кислотність зросла на 23, а у зразку 2 на $25 \%$.

Проблема висихання сирів $є$ важливою. Що стосується масової частки вологи у виготовлених сирах, то у процесі їх зберігання вміст вологи знижувався в обох досліджуваних зразках. Так, у зразку 1 масова частка вологи знизилася з 78 до $74 \%$, у зразку 2 - з 75 до $72,5 \%$. 


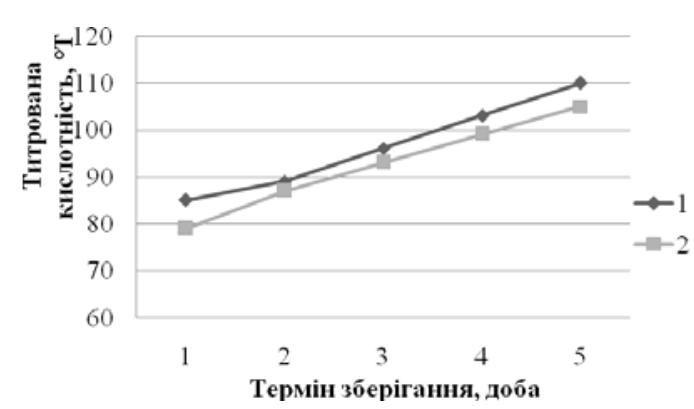

Рис. 2. Зміна титрованої кислотності альбумінового сиру рікотта протягом зберігання

Важливими є мікробіологічні дослідження в процесі зберігання сиру, оскільки їх результати свідчать про безпечність продуктів. Динаміка мікробіологічних показників альбумінових сирів протягом зберігання при температурі $(4 \pm 2){ }^{\circ} \mathrm{C}$ наведена у табл. 5 . КМАФАнМ у процесі зберігання збільшується у двох зразках сиру.

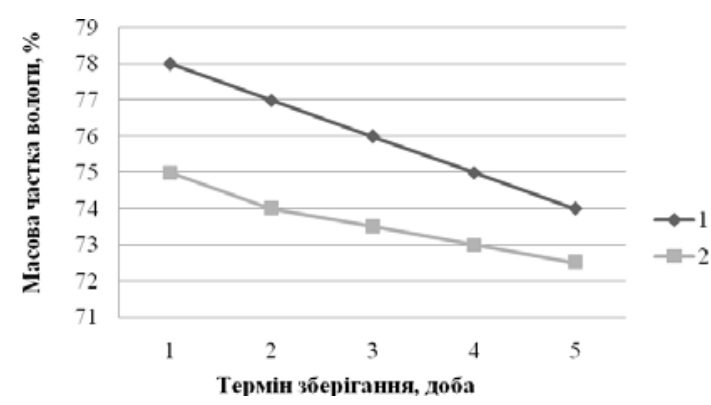

Рис. 3. Зміна масової частки вологи альбумінового сиру рікотта протягом зберігання

Слід також відзначити, що у зразку 1 кількість мікроорганізмів в сирі на початку зберігання та протягом зберігання була незначно вищою порівняно із зразком 2. 3 огляду допустимого рівня КМАФАнМ у сирі не більше $1 \times 10^{5} \mathrm{KУО/Г,} \mathrm{термін} \mathrm{зберігання} \mathrm{двох}$ зразків сиру 5 діб.

Таблиця 5

Зміна мікробіологічних показників альбумінового сиру рікотта протягом зберігання

\begin{tabular}{|c|c|c|c|c|}
\hline \multirow{2}{*}{ Сир рікотта } & \multicolumn{4}{|c|}{ Кількість мікроорганізмів в альбуміновому сирі рікотта при зберіганні через } \\
\hline & 1 добу & 3 доби & 5 діб & 7 діб \\
\hline \multicolumn{5}{|c|}{ КМАФАнМ, КУО/Г } \\
\hline Зразок 1 & $2,4 \times 10^{3}$ & $3,9 \times 10^{3}$ & $4,5 \times 10^{4}$ & $5,6 \times 10^{5}$ \\
\hline Зразок 2 & $1,9 \times 10^{3}$ & $3,1 \times 10^{3}$ & $3,5 \times 10^{4}$ & $4,4 \times 10^{5}$ \\
\hline \multicolumn{5}{|c|}{ Бактерії групи кишкової палички (БГКП) в 0,001 г продукту } \\
\hline $\begin{array}{l}\text { Зразок } 1 \\
\text { Зразок } 2\end{array}$ & не виявлено & не виявлено & не виявлено & не виявлено \\
\hline \multicolumn{5}{|c|}{ Дріжджі і плісені, КУО/г } \\
\hline $\begin{array}{l}\text { Зразок } 1 \\
\text { Зразок } 2 \\
\end{array}$ & не виявлено & не виявлено & не виявлено & не виявлено \\
\hline \multicolumn{5}{|c|}{ Патогенні мікроорганізми, в т.ч. Salmonella в 25 г продукту } \\
\hline $\begin{array}{l}\text { Зразок } 1 \\
\text { Зразок } 2 \\
\end{array}$ & не виявлено & не виявлено & не виявлено & не виявлено \\
\hline \multicolumn{5}{|c|}{ Staphylococcusaureus, в 1 г продукту } \\
\hline $\begin{array}{l}\text { Зразок } 1 \\
\text { Зразок } 2 \\
\end{array}$ & не виявлено & не виявлено & не виявлено & не виявлено \\
\hline
\end{tabular}

Відсутність БГКП, дріжджів і плісені в продуктах протягом всього періоду досліджень свідчить про ефективність вибраного режиму теплового оброблення сироватки під час виробництва альбумінових сирів.

\section{Висновки}

Для виробництва сиру рікотта використали сироватку, що утворилися при виробництві сиру моцарелла за використання для зсідання білків лимонної кислоти та заквашувальної культури прямого внесення.

Розроблено технологію альбумінного сиру рікотта iз сироватки, отриманої при застосуванні різних коагулянтів. Встановлено вплив виду сироватки на вихід, органолептичні та фізико-хімічні показники альбумінного сиру рікотта.

Встановлено зміни мікробіологічних показників в сирі протягом зберігання, які полягали у зростанні КМАФАнМ у двох зразках сиру. Показники титрова- ної кислотності протягом зберігання корелювали із зміною КМАФАнМ. Масова частка вологи у всіх зразках сиру під час зберігання зменшувалася.

Перспективи подальших досліджень. Подальші дослідження полягатимуть у розробленні технології виробництва сиру моцарелла $з$ функціональними властивостями.

\section{References}

Bilyk, O.Ia., Dronyk, H.V., Slyvka, N.B., \& Hutyi, B.V. (2017). Rozrakhunok retseptur ta rozrobka tekhnolohichnoi skhemy vyrobnytstva albuminovoho syru "Urda" dlia promyslovykh pidpryiemstv. Naukovyi visnyk LNUVMBT imeni S.Z. Gzhytskoho, 19(75), 65-71. doi: 10.15421/nvlvet7513 (inUkrainian). Cisaryk, O.J., Myhajlyc'ka, O.R., Slyvka, N.B., \& Turchyn, I.M. (2014). Tehnologija molochnyh produktiv $\mathrm{z}$ vtorynnoi' syrovyny, Liga-Pres (in Ukrainian). 
Hramcov, A.G., \& Vasilisin, S.V. (2003). Promyshlennaja pererabotka vtorichnogo syr'ja: obezzhirennoe moloko.Molochnaja syvorotka (in Ukrainian).

Silva, R.C., Minim, V.P., Vidigal, M.C.,Silva, A.N., Simiqueli, A.A., \& Minim, L.A. (2012). Sensory and Instrumental Consistency of Processed Cheeses. Journal of Food Research, 1(3), 204-213. doi: 10.5539/jfr.v1n3p204.

Mironenko, I.M., \& Chorej, E.V. (2009). Osobennosti pererabotki syvorotochnyh belkov moloka. Syrodelie i maslodelie, Deliprint, 9, 40-41 (in Ukrainian).

Grek, O.V., Polishhuk, G.Je., \& Onoprijchuk, O.O. (2010). Tehnologija produktiv zi znezhyrenogo moloka, molochnoi' syrovatky i masljanky: Navch. posib. (in Ukrainian).

Hramcov, A.G., Rjabceva, S.A., \& Evdokimov, I.A. (2009). Mirovye tendencii v pererabotke syvorotk. Pererabotka moloka, 5, 18-20 (in Russian).

Farrell, H.M., Jimenez-Flores R., Bleck., G.T., \& Brown, E.M. (2004). Nomenclature of the proteins of cow's milk - sixth revision. J. Dairy Sci., 87, 1641-1674. doi: 10.3168/jds.S0022-0302(04)73319-6.

Fox, P.F., \& Mulvihill, D.M. (1982). Milk proteins: molecules, colloida and functional properties. J. Dairy Res, 49(4), 679-693. doi: 10.1017/S0022029900022822.

Shergin, N.A., \& Kurtova, E.N. (2006). Bezothodnaja pererabotka podsyrnoj syvorotki na Uglichskom syrodel'nom zavode. Molochnaja promyshlennost', 6, 38-39 (in Russian).

Hramcov, A.G., \& Vasilisin, S.V. (2004). Spravochnik tehnologa molochnogo proizvodstva. T. 5. Tehnologija i receptury. Produkty iz obezzhirennogo moloka, pahty i molochnoj syvorotki (in Russian).

Lucey, J.A., Johnson, M.E., \& Home, D.S. (2003). Perspectives on the basis of the rheology and texture properties of cheese. Journal of Dairy Science, 86, 2725-2743. doi: 10.3168/jds.S0022-0302(03)73869-7. Manderson, G.A., Hardman, M.J., \& Creamer, L.K. (1998). Effect of heat treatment on the conformation and aggregation of $\beta$-lactoglobulin A, B and C. J. Agr. And Food Chem., 46(12), 5052-5061. doi: $10.1021 /$ jf980515y. 